\title{
Acute Renal Failure Associated with Combined Gentamicin and Cephalothin Therapy
}

\author{
J. P. FILLASTRE, R. LAUMONIER, \\ J. LEROY, M. ROBERT \\ G. HUMBERT \\ D. DUBOIS, J. METAYER, \\ A. DELPECH,
}

British Medical fournal, 1973, 2, 396-397

\section{Summary}

Three patients with normal renal function developed acute renal failure between the ninth and twenty-seventh days of combined gentamicin and cephalothin therapy. The dose of gentamicin (4-6 mg/kg/day) was in the normal range, but that of cephalothin $(180 \mathrm{mg} / \mathrm{kg} / \mathrm{day})$ was abnormally high. The nephropathy was of the tubularinterstitial type and the clinical picture similar to that seen in acute drug-induced nephropathies. Frusemide was given only after the onset of renal failure. In these three patients the high intravenous doses of cephalothin combined with gentamicin were probably nephrotoxic.

\section{Introduction}

Though some antibiotics of the classes to which gentamicin and cephalothin belong are known to be nephrotoxic, gentamicin and cephalothin themselves have up till now been thought to be non-toxic. The dosage of gentamicin is reduced in uraemia to avoid vestibular damage from an accumulation of the drug, since its plasma half life is increased when the glomerular filtration rate is low, but cephalothin may be given in renal failure without much danger of accumulation. We report here three cases of acute renal failure during treatment with high doses of cephalothin combined with normal doses of gentamicin. The nephropathies in each case were of the tubular-interstitial type.

\section{Case 1}

A 38-year-old woman became ill with acute enteritis and pyrexia. Staphylococcus aureus was isolated from the faeces but not from the blood or urine. Renal function was normal. Treatment was begun with cephalothin $12 \mathrm{~g} /$ day $(200 \mathrm{mg} / \mathrm{kg})$ intravenously and gentamicin $240 \mathrm{mg} /$ day $(4 \mathrm{mg} / \mathrm{kg})$ intramuscularly. After 25 days' treatment nausea and vomiting developed, and after 27 days the patient became oliguric. Urinary output was reduced to $200 \mathrm{ml} / 24 \mathrm{hr}$, the blood urea and serum creatinine were $250 \mathrm{mg} / 100 \mathrm{ml}$ and $18 \mathrm{mg} / 100 \mathrm{ml}$ respectively, and the urea excretion $3 \mathrm{~g} / 24 \mathrm{hr}$. Urinary protein varied between 0.6 and $0.9 \mathrm{~g} / 24 \mathrm{hr}$ and was tubular in type. Both kidneys were enlarged.

Frusemide was given over eight days to a total dose of $4.5 \mathrm{~g}$ and diuresis achieved. Cephalothin $3 \mathrm{~g} /$ day was continued for 14 days. The blood urea fell progressively, and after 49 days was $30 \mathrm{mg} / 100 \mathrm{ml}$. After four months there was no proteinuria and the creatinine clearance was $92 \mathrm{ml} / \mathrm{min}$.

\footnotetext{
Höpital Charles Nicolle, Centre Hospitalier et Universitaire de Rouen, Rouen, France

J. P. FILLASTRE, M.D., Professeur Agrégé Nephrologie

R. LAUMONIER, M.D., Professeur Anatomo-pathologie

R. LAUMONIER, M.D., Professeur Anatomo-pathologie

G. HUMBERT, M.D., Professeur Ma

D. DUBOIS, M.D., Chef de Clinique

J. METAYER, M.D., Médecin Assistant

A. DELPECH, M.D., Médecin Assistant

M. ROBERT, M.D., Médecin Assistant
}

Biopsy of renal tissue obtained percutaneously on the 37th day of the illness showed an enlarged, oedematous interstitium with little cellular infiltration. A single focus of mononuclear cells was seen at the corticomedullary junction. The glomeruli were normal except for two which showed slight mesangial thickening. The tubules were dilated and empty and the epithelium was flattened. Immunofluorescence did not show the presence of IgG, IgA, IgM, or $\beta_{1} C$ globulins or fibrinogen, and no antibodies to cephalothin or gentamycin were found by indirect Coombs test or direct agglutination. The lymphoblast transformation test was also negative to these two antibiotics.

\section{Case 2}

A 32-year-old woman with ulcerative colitis was treated from August to December 1971 with various antibiotics. On 7 December she had an acute exacerbation of her illness with pyrexia; frequent, purulent stools; and polyarthritis. Her blood urea was $20 \mathrm{mg} / 100 \mathrm{l}$. and there was no proteinuria. Treatment was begun with cephalothin $10 \mathrm{~g} /$ day $(180 \mathrm{mg} / \mathrm{kg})$ intravenously and gentamicin $240 \mathrm{mg} /$ day $(4.28 \mathrm{mg} / \mathrm{kg})$ intramuscularly. After 11 days the patient developed nausea and vomiting and her urinary output fell to $300 \mathrm{ml} / 24 \mathrm{hr}$. There was no dehydration and the body weight remained stable. On the 14th day the blood urea rose to $200 \mathrm{mg} / 100 \mathrm{ml}$ and serum creatinine to $7-8 \mathrm{mg}$ / $100 \mathrm{ml}$. The plasma sodium was $138 \mathrm{mEq} / \mathrm{l}$, chloride $86 \mathrm{mEq} / 1$., potassium $3.7 \mathrm{mEq} / 1$., and bicarbonate $8 \mathrm{mEq} / 1$. Total plasma proteins were $5.9 \mathrm{~g} / 100 \mathrm{ml}$ and the packed cell volume $32 \mathrm{ml} / 100 \mathrm{ml}$. Both kidneys were enlarged.

Frusemide, $320 \mathrm{mg}$ intravenously, was given on two successive days, producing a diuresis of 1,400 and $2,200 \mathrm{ml}$ respectively. Proteinuria and leucocyturia were present but no haematuria or bacteriuria. The blood urea gradually fell and was normal after 38 days.

Biopsy of renal tissue obtained percutaneously on the 45th day showed no glomerular or vascular lesions. The interstitium was enlarged, oedematous, and infiltrated in places with mononuclear cells. The tubules were dilated and contained granular casts. As in case 1, immunofluorescence studies were negative and no cephalothin or gentamicin antibodies were found.

\section{Case 3}

A 63-year-old man with staphylococcal septicaemia was treated with cephalothin $12 \mathrm{~g} /$ day $(218 \mathrm{mg} / \mathrm{kg})$ intravenously and gentamicin $320 \mathrm{mg} /$ day $(6 \mathrm{mg} / \mathrm{kg}$ ) intramuscularly. Renal function was normal at the start of treatment, but his blood urea rose progressively and was $60 \mathrm{mg} / 100 \mathrm{ml}$ after eight days, $90 \mathrm{mg} / 100 \mathrm{ml}$ after 12 days, and $120 \mathrm{mg} / 100 \mathrm{ml}$ after 17 days, when the serum creatinine was $2.5 \mathrm{mg} /$ $100 \mathrm{ml}$. Urinary output remained constant at between 2,000 and $2,600 \mathrm{ml} / 24 \mathrm{hr}$. Proteinuria, shown by starch gel electrophoresis to be tubular in type, appeared on the eighth day. Urinary lysozyme, measured by Ossermann's method, was $35 \mathrm{mg} / 24 \mathrm{hr}$ on the 13th day and $85 \mathrm{mg} / 24 \mathrm{hr}$ on the $18 \mathrm{th}$ day. There was leucocyturia but no bacteriuria or abnormal haematuria. Cephalothin and gentamicin were withdrawn after 18 days and replaced by pristinamycin $2 \mathrm{~g} /$ day. After 31 days the blood urea had returned to normal and after two months the creatinine clearance was also normal.

Biopsy of renal tissue obtained percutaneously on the 22nd day showed normal glomeruli and interstitium but some dilated tubules containing granular casts. There was no polynuclear leucocyte infiltration.

Electron microscopy showed normal tubular microvilli but a slight fibrosis was present under the basal membrane. Immunofluorescence studies were negative and no antibodies to cephalothin or gentamicin were found. 


\section{Discussion}

Since cephalothin and gentamicin were thought not to be highly nephrotoxic, the cause of the renal failure in these three cases was not at first evident. Pre-existing renal disease could be excluded but infection had to be considered, especially in the third case. The absence of polynuclear lymphocyte infiltration, however, seemed to rule out infection. The clinical picture and histological findings were rather those of an acute drug-induced interstitial nephropathy, and this was the diagnosis made.

In young rats gentamicin $200 \mathrm{mg} / \mathrm{kg} /$ day causes oedema of the epithelium of the proximal tubules and occasional cellular desquamation. Areas of regeneration are found in some damaged zones. In older rats a lower dose of $100 \mathrm{mg} / \mathrm{kg} /$ day causes more marked lesions. The nuclei of the swollen epithelial cells are pyknotic and in places there is necrosis. The tubules are separated by an interstitial oedema rich in cells. These lesions produce neither clinical signs nor change in renal function. In rats in whom the number of nephrons has been experimentally reduced gentamicin $100 \mathrm{mg} / \mathrm{kg} /$ day causes extensive tubular necrosis. The existing renal failure is aggravated and there is a noticeable rise in blood urea (Flandre and Damon, 1967). In cats gentamicin in doses of from 2.5 to $10 \mathrm{mg} / \mathrm{kg} /$ day for 42 days does not cause any change in urinary output, electrolytes, or creatinine clearance or histological changes. In dogs at least $40 \mathrm{mg} / \mathrm{kg}$ /day of gentamicin must be given to cause tubular necrosis and an increase in blood urea (Bulger et al., 1963). In man gentamicin seems to be well tolerated by the kidneys (Bertoye et al., 1969; Stahl et al., 1969).

Large doses $(200-500 \mathrm{mg} / \mathrm{kg})$ of cephalothin are not nephrotoxic to rabbits and monkeys (Perkins et al., 1960) whereas comparable doses of cephaloridin cause necrosis of the epithelium of the proximal tubules. Cephaloridin is excreted unchanged in its active form. Cephalothin is metabolized into O-desacetylcephalothin, which is 10 times less active. There are only a few reported cases of acute renal failure in man in which cephalothin might have been the cause (Simpson, 1971; Steinbrunn and Haemmerli, 1967; Rahal et al., 1968; Pickering et al., 1970).

Gentamicin 4-6 mg/kg/day or cephalothin $60-100 \mathrm{mg} / \mathrm{kg} /$ day given over a period of 30 to 60 days do not seem to be nephrotoxic, and a combination of these antibiotics in the treatment of severe Gram-negative infections is fully justified. In the first 100 patients so treated in our unit in 1972 six developed proteinuria after six days, in three the urinary lysozyme excretion was increased, and in two the blood urea, normal at first, rose to 60 and $70 \mathrm{mg} / 100 \mathrm{ml}$ respectively. All these except one had received gentamicin $240 \mathrm{mg} /$ day, the exception received $360 \mathrm{mg}$ day with cephalothin up to $6 \mathrm{~g} /$ day.
In the present three cases the dosage of gentamicin was normal but that of cephalothin was abnormally high. Probably the two drugs were synergistic in their nephrotoxic effect. Opitz et al. (1971) found impaired renal function in eight patients (average age 72) being treated with high doses of cephalothin (12-16 $\mathrm{g} /$ day) combined with the usual dose of gentamicin ( $240 \mathrm{mg} /$ day). Unfortunately the nature of the renal impairment was not reported.

Our three patients were given frusemide only after the onset of renal failure. Dodds and Foord (1970) showed that the nephrotoxicity of cephalosporin to dogs and rabbits was increased in the presence of frusemide. Recently Linton et al. (1972), studying the nephrotoxicity of cephalosporins combined with frusemide in an animal model, induced a mild transitory renal impairment with glycerol. Cephaloridine and cephalothin given in subnephrotoxic doses in combination with frusemide caused acute, extensive tubular necrosis at serum antibiotic concentrations not much higher than those obtained in clinical practice. The authors suggested that the cephalosporins should be used with care in the presence of even minor renal impairment, particularly if frusemide was being given concurrently.

Large doses of frusemide are now advocated in acute renal tubular disease, but when a toxic nephropathy is suspected it might be wise to proceed cautiously.

\section{References}

Bertoye, A., Vincent, P., and Bolot, J. F. (1969). Symposium Gentalline, Palma de Majorque, vol $1, \mathrm{p} .71$.

Bulger, R. J., Sidell, S., and Kirby, W. M. M. (1963). Annals of Internal Medicine, 59, 593.

Dodds, M. G., and Foord, R. D., (1970). British fournal of Pharmacology, 40, 227.

Flandre, O., and Damon, M. (1967). Gentamicin, First International Symposium, Paris.

Linton, A. L., Barley, R. R., and Turnbull, D. I. (1972). Canadian Medical Association fournal, 107, 414.

Opitz, A., Herrmann, I. V., Herrath, D., and Schaefer, K. (1971). Medizinische $W$ zlt, 22, 434 .

Perkins, R. L., Apicella, M. A., In-Sung-Lee, Cuppage, F. E., and Saslaw, S. (1960). American fournal of the Medical Sciences, 257, 116.

Pickering, M. J., Spooner, G. R., de Quesada, A., and Cade, J. R. (1970). Southern Medical Fournal, 63, 426.

Rahal, J. J., Meyers, B. R., and Weinstein, C. (1968). New England fournal of Medicine, 279, 1305.

Simpson, I. J. (1971). New Zealand Medical fournal, 74, 312.

Stahl, J., et al. (1969). Symposium Gentalline, Palma de Majorque, vol. 1, p. 201.

Steinbrunn, W., and Haemmerli, U. P. (1967). German Medical Monthly, 12,171 . 